\title{
PENGEMBANGAN KLASTER TANAMAN CABAI DI KABUPATEN AGAM PROVINSI SUMATERA BARAT
}

\author{
Eri Gas Ekaputra"), Feri Arlius, Omil Charmyn Chatib, dan Fadli Irsyad \\ Jurusan Teknik Pertanian Fakultas Teknologi Pertanian Universitas Andalas \\ ${ }^{*}$ Email: erigas@ @otmail.com
}

\begin{abstract}
ABSTRAK
Cabai merupakan salah satu komoditas hortikultura yang paling diminati di masyarakat seperti halnya bawang merah, dan bawang putih. Hal ini dikarenakan komoditas tersebut dibutuhkan disetiap lapisan masyarakat, terutama di Provinsi Sumatera Barat. Permintaan terhadap cabai biasanya akan semakin tinggi menjelang hari istimewa seperti lebaran, tahun baru, dan hari besar nasional. Tingginya permintaan tersebut akan menyebabkan kenaikan harga cabai di pasaran, diperparah dengan musim hujan dan cuaca ekstrim, hal ini akan menyebabkan produksi cabai menjadi terhambat hingga gagal panen pastinya akan terjadi kenaikan harga yang cukup signifikan. Tantangan yang dihadapi dalam pengembangan klaster nasional cabai tersebut adalah perlu adanya dukungan teknologi pertanian serta upaya penumbuhan kelembagaan sehingga diperlukan pendampingan yang intensif. Kepentingan masingmasing petani yang beragam dapat menjadi tantangan sekaligus peluang dalam penyadaran petani untuk berkelompok. Sehingga perlakuan dominasi pengumpul cabe dengan melakukan kegiatan spekulatif menjual cabai di suatu wilayah dengan harga yang tinggi mengakibatkan adanya supply shock yang pada akhirnya dapat memicu inflasi pada wilayah sentra cabai. Perubahan iklim wilayah yang terjadi pada tingkat probabilitas yang bervariasi berkisar antara $58 \%-100 \%$. Parameter iklim yang mengalami tren signifikan yaitu; kecepatan angin kumulatif dan maksimum dengan tren negatif pada probabilitas $100 \%$, kelembaban relatif rata-rata dan minimum dengan tren positif pada probabilitas sebesar $100 \%$, dan Evaporasi dengan tren positif pada probabilitas rata-rata $95 \%$. Berdasarkan perhitungan neraca air pada Stasiun Candung didapatkan jadwal tanam cabai yang tepat berada pada Bulan Februari. Sedangkan pada Stasiun Matur, jadwal yang tanam cabai dapat dilakukan pada Bulan Mei, dan Stasiun Gobah pada Bulan Januari. Diharapkan kepada petani cabai untuk menyesuaikan jadwal tanam cabai pada bulan tersebut agar mendapatkan kuantitas dan kualitas cabai yang diharapkan.
\end{abstract}

Kata Kunci: klaster cabai, pendampingan masyarakat, aplikasi teknologi, pascapanen cabai, jadwal tanam cabai.

\section{Development of Cluster of Cabai Plants in Agam District, West Sumatera Province}

\begin{abstract}
Chili is one of the most popular horticultural commodities in the community as well as shallots and garlic. This is because the commodity is needed in every level of society, especially in the Province of West Sumatra. Demand for chili will usually be higher ahead of special days such as Eid, New Year and national holidays. The high demand will cause an increase in the price of chilli peppers on the market, compounded by the rainy season and extreme weather, this will cause the production of chillies to be hampered until crop failures will certainly be a significant price increase. The challenges faced in developing the national chili cluster are the need for agricultural technology support and efforts to develop institutions so that intensive assistance is needed. The diverse interests of each farmer can be both a challenge and an opportunity to raise awareness of farmers for groups. So that the treatment of the dominance of chilli collectors by conducting speculative activities selling chili in an area with high prices resulted in supply shock which in turn could trigger inflation in the central region of chili. Regional climate change that occurs at varying degrees of probability ranges from 58\% - 100\%. Climate parameters that experience a significant trend are; cumulative and maximum wind speed with a negative trend on $100 \%$ probability, average and minimum relative humidity with a positive trend on a probability of $100 \%$, and Evaporation with a positive trend on an average probability of $95 \%$. Based on the
\end{abstract}


calculation of the water balance at the Candung Station, the chili planting schedule is right in February. Whereas at Matur Station, chili planting schedules can be carried out in May, and Gobah Station in January. It is expected that chili farmers will adjust the chili planting schedule for the month in order to obtain the quantity and quality of chili expected.

Keywords: chili cluster, community assistance, technology application, chili postharvest, chili planting schedule.

\section{PENDAHULUAN}

Produksi tanaman cabai di Sumbar dapat dikatakan masih sedikit dan tersebar di berbagai Kabupaten/ Kota. Petani hanya membudidayakannya pada lahan yang seadanya dan biasanya kurang dari 0,5 ha. Petani belum barani membudidayakan cabai pada lahan yang luas dan pada kondisi musim hujan. Pada kondisi ini tidak jarang pedagang/pengusaha mendatangkan komoditas tersebut dari luar daerah, seperti Kerinci, Provinsi Sumatera Utara, Jawa Barat, dan wilayah lainya guna memenuhi kebutuhan tersebut. Hal ini menjadikan harga cabai semakin tinggi akibat cost (biaya) yang dikeluarkan untuk sarana transportasi yang cukup mahal.

Produksi cabai Sumatera Barat berada pada peringkat ke tiga di Pulau Sumatera dengan luas panen ditahun 2012 sebesar 8196 ha dengan produksi 65108 ton. Produksi cabai tertinggi berada di Sumatera Utara sebesar 245773 ton dengan luas panen 22129 ha, dan Provinsi Aceh sebesar 90.030 ton dengan luasan panen hanya 8133 ha (BPS 2013). Dilihat dari segi konsumsi Nasional untuk Cabai perkapita di tahun 2012 sebesar 1,42 kg/org/tahun. Jika $10 \%$ penduduk Sumbar mengkonsumsi Cabai ditahun 2012, maka dibutuhkan Cabai sebesar 706047 ton Cabai di tahun tersebut (dengan jumlah penduduk 4.972.162 jiwa). Hal ini menandakan kekurangan pasokan cabai di Sumatera Barat, karena Sumbar hanya mampu menyediakan 130216 ton cabai di tahun 2012 (asumsi panen 2 kali dalam satu tahun).

Perlu adanya peningkatan produksi cabai di Sumatera Barat baik dari segi luasan lahan tanaman cabai, dan produktifitasnya, dengan luasan tanaman cabai akan meningkatkan produksi cabai. Selanjutnya dapat dilakukan dengan intensifikasi dengan penerapan teknologi pengendalian hama dan penyakit menjadikan produksi tanaman cabai meningkat. Serta dibutuhkan suatu metode tepat guna (sepadan) dan keterampilan bagi petani yang benar-benar kompeten dalam budidaya tanaman cabai, seperti peningkatan kapasitas petani menjadi pakar dalam melaksanakan usaha tani cabe mulai dari; (i) penentuan lokasi yang sesuai untuk budidaya cabai, (ii) pengaturan sistem irigasi dan drainase, (iii) pemilihan benih unggul, (iv) $\mathrm{pH}$ dan kondisi tanah, (v) penanganan terhadap hama dan penyakit, serta (vi) tindakan pencegahan terhadap serangan virus.

Kabupaten Agam merupakan salah satu wilayah yang memiliki kondisi ideal dalam budidaya cabai dinataranya hampir setengah luasan Kab Agam (44,55\%) berada pada ketinggian 0-500 m dpl. Selain itu Kab. Agam memiliki wilayah dengan kelas hujan yang cukup sesuai dengan tanaman cabai yakni pada daerah dengan curah hujan 3500$4000 \mathrm{~mm} /$ tahun dengan bulan kering selama 1-2 bulan berturut-turut meliputi sebagian Kecamatan Palembayan, Palupuh, dan IV Koto. Serta kawasan dengan curah hujan 2500-3500 mm/tahun dengan bulan kering selama 1-2 bulan berturut- turut, meliputi sebagian wilayah Kecamatan Lubuk Basung dan Tanjung Raya. Sementara itu, sektor pertanian telah memberikan sumbangan terbesar bagi Produk Domestik Regional Bruto 
(PDRB) Kabupaten Agam, sumbangan nilai tambah dari sektor pertanian pada tahun 2012, terdapat PDRB mencapai 39,72\%, dengan laju pertumbuhan sebesar 7,01\%".

\section{METODE}

Kegiatan ini dilaksanakan pada bulan Februari s/d November 2017, yang berlokasi di Kabupaten Agam. Mengingat komitmen ketahanan pangan Kabupaten Agam akan tetap dipertahankan. Sampai saat ini Kabupaten Agam dalam program jangka menengah (RPJM) 2010-2015 menunjang ketahan pangan maka untuk memenuhi kebutuhan cabai dan dapat menekan inflasi maka dilakukan pengembangan klaster cabai dengan pendekatan sistem pertanian cabai intensif dalam kawasan yang disusun secara berjenjang dari tingkat kelompok (Nagari) sampai tingkat wilayah kecamatan.

Pengembangan Klaster Tanaman Cabai pada Kabupaten Agam, Provinsi Sumatera Barat ini dibagi ke dalam tiga tahapan.

Tahun pertama :

a. Mengidentifikasi permasalahan pengembangan dan agribisnis cabai di Kab.Agam

b. Melakukan Research and Development tanaman cabai di kelompok tani

c. Pemetaan permasalahan dan pengembangan agribisnis cabai.

Tahun Kedua :

a. Aplikasi pengelolaan agribisnis pada level Kelompok (Nagari), Kecamatan sampai ke kabupaten dengan keterlibatan stakeholders

b. Pengembangan kelembagaan, jaringan penyangga agribisnis cabai melalui penguatan sistem pasar dan perdagangan cabai

c. Penguatan sistem informasi agribisnis cabai

d. Peningkatan kapasitas pasok cabai melalui penambahan kawasan tanam cabai melalui pengaturan pola tanam, jadwal tanam, agar terjaganya produksi cabai di tingkat kelompok (Nagari) Kecamatan sampai Kabupaten.

Tahun Ketiga :

a. Peningkatan dan pembangunan infrastruktur rantai pasokan cabai, hingga membangun jejaring dengan industri hilir cabai

b. Pasca panen cabai.

c. Melibatkan petani pakar dalam kegiatan capacity building pada kawasan pengembangan agribisnis.

d. Mempertahankan produksi cabai serta kualitas dan ketersediaan setiap saat.

Strategi dalam melaksanakan kegiatan tersebut dilakukan dalam tiga tahun, seperti peta perjalanan (roadmap) rencana kegiatan. Kegiatan ini selalu melibatkan seluruh stakeholders yang memiliki peranan dalam pengembangan kluster cabai pada kabupaten Agam. Adapun roadmapnya dapat dilihat pada gambar berikut. 


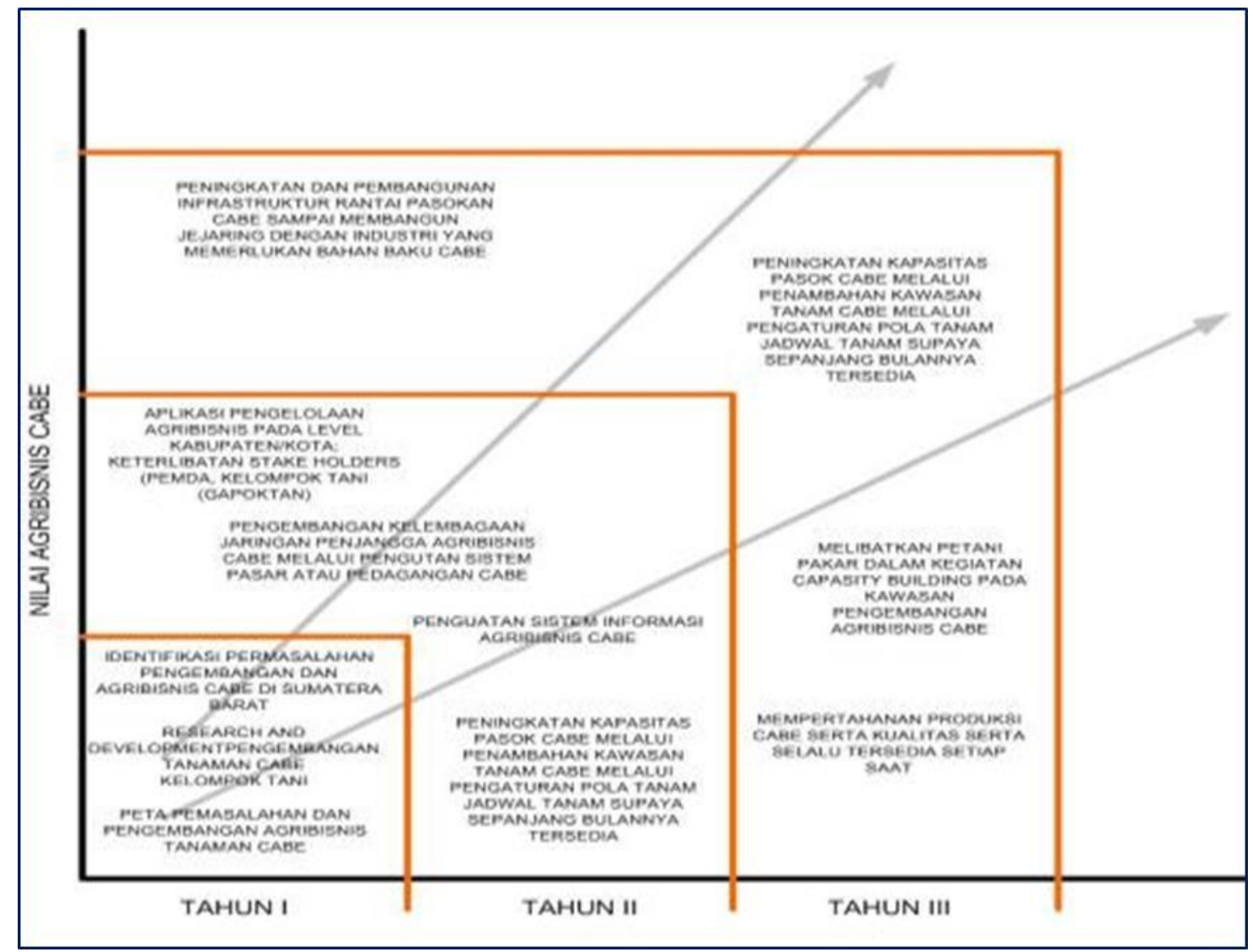

Gambar 1. Roadmap Kegiatan Klaster Tanaman Cabai Kabupaten Agam

Program aksi Nagari mandiri pangan yang disusun, mengacu pada program kerja pembangunan pertanian di kawasan Kabupaten Agam melalui upaya peningkatan ketahanan pangan dan peningkatan kesejahteraan petani. Dengan bertitik tolak pada sasaran yang akan dicapai berupa terujudnya ketahanan pangan. Maka kegiatan ini disusun berdasarkan melihat peluang potensi dan permasalahan ketahanan pangan ditingkat mikro dan makro.

\section{HASIL DAN PEMBAHASAN}

Pembuatan damplot klaster cabai telah dilaksanakan di Nagari Biaro Kecamatan Ampek Angkek Kabupaten Agam. Damplot ini merupakan wadah pembelajaran budidaya cabai untuk kelompok tani disekitar lokasi. Hasil analisis data untuk total luasan tanam di Kabupaten Agam telah terjadi peningkatan setiap tahunnya. Hal ini menandakan minat petani untuk melaksanakan budidaya tanaman cabai relatif tingggi. 


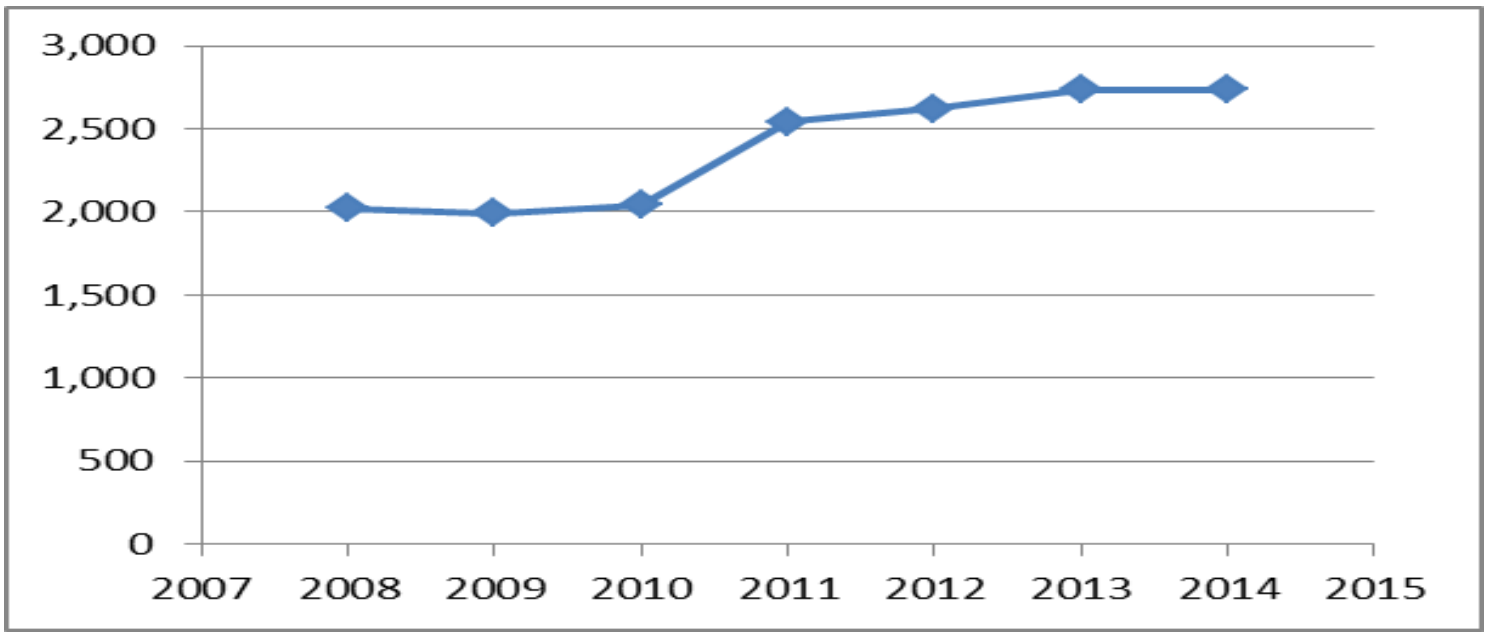

Gambar 2. Grafik Peningkatan Luas Tanam Cabai di Kabupaten Agam

Dari data yang diperoleh juga menunjukkan produksi cabai di Kabupaten Agam pada tahun 2015 mencapai 12.141 ton, dengan tingkat produktivitas mencapai 5,14 hal ini menjadi tingkat produktivitas tertinggi dari seluruh tahun. Produk cabai merah bersifat mudah rusak, menyusut dan cepat membusuk, sehingga kegiatan penanganan panen dan pascapanen merupakan salah satu mata rantai yang sangat penting. Teknik penanganan panen dan pascapanen cabai merah yang baik akan dapat meningkatkan daya simpan dan daya guna semaksimal mungkin (Rukmana dan Yuniarsih, 2005).

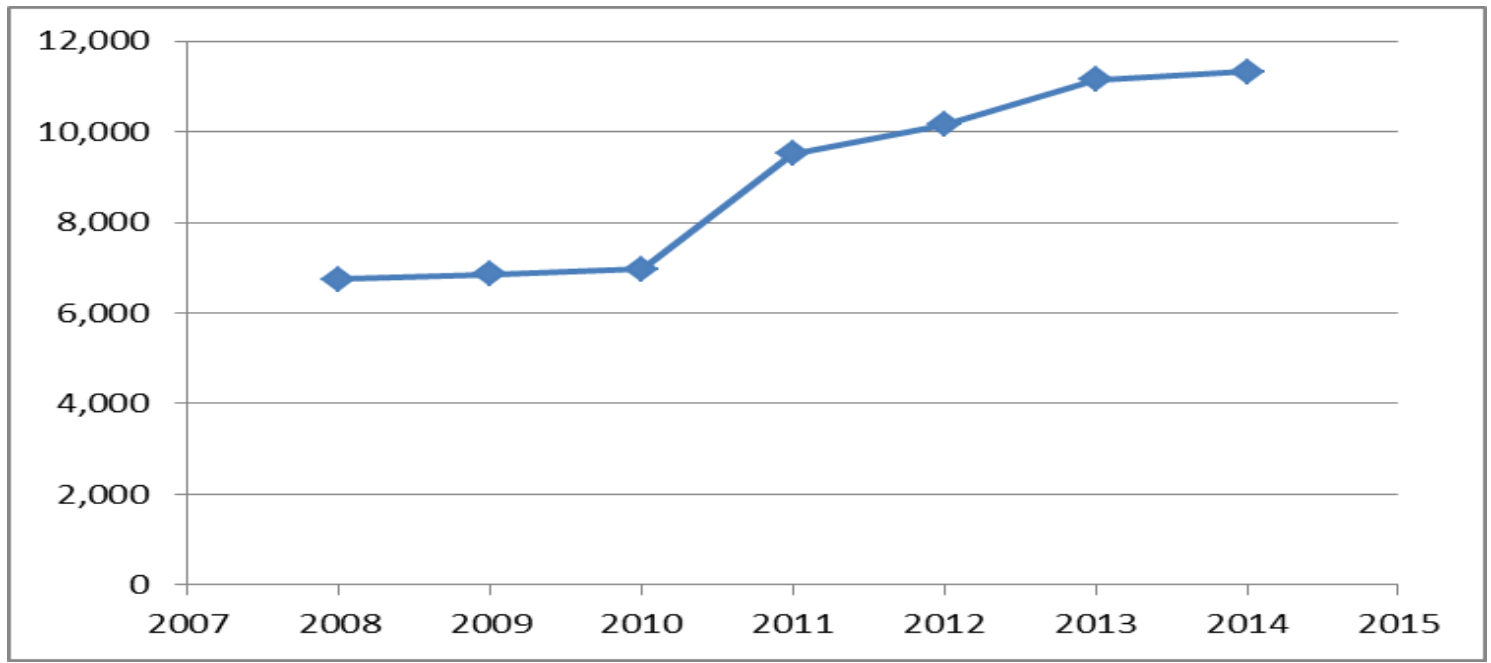

Gambar 3. Grafik Peningkatan Produksi Cabai di Kabupaten Agam

\section{Pendampingan Kelompok Tani Cabai}

Pendampingan yang telah dilakukan yakni pada Kelompok Tani Biaro Sepakat di nagari Biaro, Kecamatan Ampek Angkek, selanjutnya di Kecamatan Matua yang merupakan sentral cabai di Kab. Agam yakni pada Kelompok Tani Harapan Karya, Tali Tigo Sapilin, Rumah Nan Gadang di Nagari Matua Mudiak, Kelompok Tani Usaha Sepakat di Nagari Tigo Balai. Pendampingan yang dilakukan terkait permasalahan dalam budidaya cabai dengan penerapan teknologi budidaya cabai, pelatihan 
dilaksanakan di lokasi kegiatan dengan pemberian modul agribisnis cabai.

Pada kegiatan pendampingan ini cabai yang akan digunakan merupakan cabai keriting, hal ini dikarenakan masyarakat Sumbar lebih menyukai rasa dari cabai keriting yang lebih pedas. Pada Kegiatan ini pengaturan waktu tanam sangat perlu diperhatikan. Sehingga panen dapat berlangsung sepanjang tahun. Tahapan dalam aktifitas budidaya cabai meliputi pengaturan waktu tanam budidaya cabai,pengolahan tanah, pembibitan, penanaman, pemeliharaan, pengairan, pemanenan.

Materi kegiatan Pendampingan kelompok tani dalam Pengembangan Klaster Cabai di kab. Agam dibagi menjadi 3 golongan besar, yakni materi yang berhubungan dengan aspek pengetahuan, materi yang berhubungan dengan aspek keterampilan dan materi yang berhubungan dengan aspek sikap. Materi pelatihan 25\% merupakan materi non teknis sedangkan $75 \%$ merupakan materi teknis.

\section{Penanganan Pascapanen Cabai}

Cabai bubuk instan merupakan produk cabai yang dihasilkan melalui pengeringan. Dalam proses pengolahan cabai bubuk instan ini akan menggunakan alat pengering buatan yaitu oven vakum. Suhu yang digunakan selama pengeringan yaitu 40 oC dengan waktu pengeringan sesuai dengan perlakuan yang dirancang dalam penelitian.

Rendemen merupakan salah satu parameter yang perlu diperhatikan dalam pengolahan pangan. Rendemen dipengaruhi oleh suhu, waktu, metoda pengeringan. Kadar air akan mempengaruhi rendemen yang dihasilkan. Dalam proses pengeringan, semakin tinggi kadar air maka semakin rendah rendemen yang diperoleh atau sebaliknya. Untuk meningkatkan jumlah rendemen dari hasil pengeringan cabai ini maka perlu dilakukan penambahan bahan pengisi. Bahan pengisi yang digunakan yaitu dekstrin. Menurut Suprapti (2005), dekstrin bermanfaat sebagai bahan pengisi/pembantu pada industri-industri tekstil, farmasi, makanan-minuman, dan kertas.

\section{Pengembangan Kelembagaan dan Jaringan Penyangga Agribisnis Cabai}

Selanjutnya untuk meningkatkan kesejahteraan petani cabai, perlu adanya kerjasama dengan Dinas Pertanian Tanaman Pangan, Hortikultura dan Peternakan Kab. Agam untuk memfasilitasi pemasaran cabai kepada pasar dan industri melalui program kerjasama kemitraan pemasaran cabai dengan pedagang pengumpul atau industri. Tujuan utama dari program kemitraan pemasaran dengan semata-mata untuk meningkatkan kapasitas perekonomian dan kesejahteraan petani cabai karena perlu diinformasikan bahwa marjin keuntungan dari kenaikan harga cabai di pasar secara umum tidak dinikmati sepenuhnya oleh petani cabai, namun lebih banyak diambil oleh pedagang pengumpul atau tengkulak cabai. Program kemitraan pemasaran ini direncanakan dilaksanakan pada awal bulan November tahun 2016 di Kota Lubuk Basung, Kab. Agam dengan menghadirkan Dinas Perindustrian dan Perdagangan Kab. Agam, Dinas Pertanian Tanaman Pangan, Hortikultura dan Peternakan Kab. Agam, pelaku pasar, dan Perkumpulan petani Cabai di Kab. Agam.

\section{Pembinaan dan Pengembangan Kelembagaan}

Pembinaan dan pengembangan kelembagaan dan jaringan penyangga agribisnis cabai merupakan kegiatan lanjutan dari pendampingan yang telah dilaksanakan di tahun ke dua yakni pada Kelompok Tani Biaro Sepakat di nagari Biaro, Kecamatan Ampek Angkek, selanjutnya di Kecamatan Matua yang merupakan sentral cabai di Kabupaten 
Agam yakni pada Kelompok Tani Harapan Karya, Tali Tigo Sapilin, Rumah Nan Gadang di Nagari Matua Mudiak, Kelompok Tani Usaha Sepakat di Nagari Tigo Balai.

Pembinaan yang dilaksanakan yakni pembuatan jejaring cabai di Kab. Agam. Hal ini bertujuan untuk media informasi bagi seluruh petani cabai. Tentunya ini memanfaatkan teknologi telekomunikasi.

\section{Penentuan Jadwal Tanam Cabai}

Perubahan iklim mengakibatkan perubahan pola curah hujan. Perubahan pola curah hujan menyebabkan perubahan pola musim tanam. Produksi tanaman cabai pada bulan Oktober-Maret menurun dibandingkan pada bulan kering (Juli-September). Penurunan angka produksi tanaman cabai pada bulan tersebut dibuktikan berdasarkan data BPS Sumatera Barat (2014) produksi tanaman cabai berfluktuatif selama 2011 - 2013 dengan kecenderungan naik pada triwulan 2 dan 3, kemudian turun pada triwulan ke-4. Akibatnya, harga cabai melambung pada akhir dan awal tahun murah ketika panen pada pertengahan tahun. Ketidak-stabilan pasokan setiap musimnya jika dikaitkan dengan kebutuhan tehadap cabai yang relatif stabil setiap musimnya mengakibatkan peningkatan inflasi.

Sumatera Barat merupakan salah satu provinsi sentra cabai di Indonesia dengan menyumbang sebesar 5,62 \% dan merupakan provinsi tertinggi di luar pulau Jawa dalam hal kontribusi produksi cabai besar dari tahun 2010 - 2014 (Sekjen Kementan 2015). Sebagian besar produksi cabai besar di Sumatera Barat berasal dari Kabupaten Agam dengan produksi terbanyak terdapat pada Kecamatan IV Angkek dan Matur. Meskipun demikian, masyarakat Sumatera Barat masih mengalami permasalahan dengan ketersediaan cabai dengan harga yang terjangkau pada rentang waktu yang cukup lama yaitu pada Oktober- Desember dan Januari-Maret. Maka dari itu perlu dilakukan penelitian dengan mengkaji sektor iklim yang merupakan penyebab terjadinya perubahan pola curah hujan seperti pergeseran musim hujan dan variabilitas curah hujan yang tinggi agar didapatkan informasi yang lebih akurat dalam menetapkan masa pertumbuhan tanaman cabai.

Jadwal tanam merupakan waktu yang ditetapkan untuk memulai usaha budidaya suatu tanaman pada sebidang lahan. Tanaman dalam pertumbuhan dan perkembangan nya harus berada pada masa yang tepat agar tercapai produksi yang lebih baik. Sehingga perlu dilakukan pengaturan jadwal tanam dengan mempertimbangkan faktor lingkungan.

Pengaturan jadwal tanam pada penelitian ini ditentukan berdasarkan hasil perbandingan ketersediaan air dengan kebutuhan air yaitu neraca air. Penetapan dilakukan dengan mengurutkan parameter berdasarkan faktor potensi pengaruh parameter terhadap hasil tanaman.parameter yang pertama yaitu (1) Total Defisit minimum, (3) Total Surplus minimum. Berdasarkan hasil neraca air maka jadwal tanam ditetapkan sebagai berikut :

Dilihat dari hasil analisis neraca air dari tahun 2018 s/d 2022 berdasarkan stasiun Candung didapatkan jadwal tanam yang sama setiap tahun dengan jadwal yang tepat berada pada bulan Februari. Sedangkan pada stasiun Matur jadwal tanam yang tepat berada pada bulan Mei dan Stasiun Gobah berada pada bulan Januari. 


\section{Pelaksanaan Tanam Cabai Berdasarkan Kearifan Lokal}

Lahan pertanian pada Kecamatan IV Angkek dan Kecamatan Matur pada umumnya merupakan lahan tadah hujan. Masyarakat petani dalam melakukan proses budidaya sebagian didasarkan pada perkiraan musim hujan. Penggalian informasi mengenai prilaku masyarakat petani cabai dalam melaksanakan proses budidaya cabai khususnya dalam memulai penanaman cabai maka dilakukan survey ke lapangan dengan mewawancarai petani secara langsung. Wawancara dilakukan untuk mengetahui waktu penanaman cabai pada tahun 2016 dan tahun 2017. Data Hasil wawancara ditampilkan pada Tabel 1.

Tabel 1. Data Pelaksanaan Tanam Cabai di Kecamatan IV Angkek dan Kecamatan Matur

\begin{tabular}{cccccccccc}
\hline & \multicolumn{8}{c}{ Kelompok Bulan Tanam } \\
\cline { 2 - 9 } B. Tanam & \multicolumn{1}{c}{ DJF } & \multicolumn{1}{c}{ MAMA } & \multicolumn{3}{c}{ SON } \\
\cline { 2 - 10 } & A & B & A & B & A & B & A & B \\
\hline Jan & 4 & 2 & - & - & - & - & - & - \\
Feb & 2 & 2 & - & - & - & - & - & - \\
Mar & - & - & 1 & 1 & - & - & - & - \\
Apr & - & - & 1 & 3 & - & - & - & - \\
Mei & - & - & - & - & - & - & - & - \\
Jun & - & - & - & - & - & 1 & - & - \\
Jul & - & - & - & - & - & 1 & - & - \\
Agu & - & - & - & - & 1 & - & - & - \\
Sep & - & - & - & - & - & - & 3 & - \\
Okt & - & - & - & - & - & - & - & 1 \\
Nov & - & - & - & - & - & - & - & 1 \\
Des & 1 & 1 & - & - & - & - & - & - \\
\hline Jumlah & 7 & 5 & 2 & 4 & 1 & 2 & 3 & 2 \\
\hline Kumyyyyyyyyyy
\end{tabular}

Keterangan : A = Data Kecamatan IV Angkek

$\mathrm{B}=$ Data Kecamatan Matur

Pada Tabel 1. (A) menunjukkan sebanyak 13 data bulan tanam yang digabung ke dalam kelompok bulan tanam yaitu: DJF (Desember, Januari, Februari), MAM (Maret, April, Mei), JJA (Juni, Juli, Agustus), dan SON (September, Oktober, November). Berdasarkan data tersebut pelaksanaan bulan tanam umumnya dilakukan pada kelompok bulan DJF dengan jumlah 7 petani dari 13 petani. Kelompok bulan DJF memiliki jumlah bulan tanam terbanyak yaitu Januari berjumlah 4, diikuti oleh Februari berjumlah 2 selanjutnya Desember berjumlah 1. Kelompok bulan tanam JJA merupakan kelompok bulan tanam dengan jumlah petani yang menanam cabai terkecil yaitu sebanyak 1 pada bulan Agustus.

Sedangkan berdasarkan hasil analisis neraca air pada tahun 2016 dan 2017 (Gambar 10) pada wilayah kecamatan IV Angkek didapatkan jadwal tanam terbaik berdasarkan kriteria yang ditetapkan yaitu berada pada bulan Februari dan bulan Juli. Potensi jadwal tanam hasil analisis neraca air dengan praktik tanam cabai yang dilakukan oleh petani di Kecamatan IV Angkek tidak memiliki jarak yang relatif tidak terlalu jauh. Sehingga sangat memungkinkan untuk melaksanakan proses budidaya berdasarkan jadwal tanam tersebut dengan menunda melaksanakan penanaman selama lebih kurang 1 bulan.

Berdasarkan Tabel 1. pada wilayah Stasiun Matur (B) menunjukan bahwa kelompok bulan tanam terbanyak terdapat pada kelompok DJF berjumlah sebanyak 5 petani dari 13 orang. Selanjutnya diikuti oleh Kelompok MAM berjumlah 4 petani. Pada kelompok DJF jumlah petani penanam cabai relatif sama pada ketiga bulan tanam. 
Jika dikaitkan dengan hasil analisis neraca air tanaman cabai maka tanaman cabai tumbuh dan berkembang pada bulan-bulan yang basah yang relatif cukup tinggi. Sedangkan potensi jadwal tanam yang terbaik berada pada kelompok 2 yaitu bulan Mei. Hal ini tentu akan sulit bagi petani untuk berpindah pada jadwal tersebut dengan perbedaan bulan tanam yang cukup jauh bagi petani yang melaksanakan bulan tanam kelompok DJF.

\section{KESIMPULAN DAN SARAN}

Berdasarkan hasil penelitian secara keseluruhan dapat disimpulkan: 1. tingkat produktivitas mencapai 5,14 hal ini menjadi tingkat produktivitas tertinggi dari seluruh tahun, 2. Pendampingan yang dilakukan terkait permasalahan dalam budidaya cabai dengan penerapan teknologi budidaya cabai, pelatihan dilaksanakan di lokasi kegiatan dengan pemberian modul agribisnis cabai, 3. pengaturan waktu tanam sangat perlu diperhatikan. Sehingga panen dapat berlangsung sepanjang tahun. Tahapan dalam aktifitas budidaya cabai meliputi pengaturan waktu tanam budidaya cabai,pengolahan tanah, pembibitan, penanaman, pemeliharaan, pengairan dan pemanenan, 4. Cabai bubuk instan merupakan produk cabai yang dihasilkan melalui pengeringan. Dalam proses pengolahan cabai bubuk instan ini akan menggunakan alat pengering buatan yaitu oven vakum. Suhu yang digunakan selama pengeringan yaitu $40{ }^{\circ} \mathrm{C}$ dengan waktu pengeringan sesuai dengan perlakuan yang dirancang dalam penelitian, 5. Pembinaan yang dilaksanakan yakni pembuatan jejaring cabai di Kab. Agam. Hal ini bertujuan untuk media informasi bagi seluruh petani cabai. Tentunya ini memanfaatkan teknologi telekomunikasi dan 6. Berdasarkan hasil analisis neraca air pada Stasiun yang digunakan terdapat potensi jadwal tanam yang tepat yaitu; Pada Stasiun Candung tahun 2018 s/d 2023 bulan Februari, Stasiun Matur bulan Mei, dan Stasiun Gobah bulan Januari. Berdasarkan kebiasaan pada daerah Kecamatan IV Angkek tahun 2016 s/d 2017 penanaman cabai terbanyak dilakukan pada kelompok bulan DJF. Sedangkan pada daerah Kecamatan Matur, penanaman terbanyak dilakukan pada kelompok bulan DJF dan MAM.

\section{DAFTAR PUSTAKA}

Balitbangtan. 2011. Pedoman Umum Adaptasi Perubahan Iklim Sektor Pertanian. Badan Penelitian dan Pengembangan Pertanian.

BPS Sumatera Barat. 2014. Produksi Cabai Besar, Cabai Rawit, dan Bawang Merah tahun 2013. Berita Resmi Statistik. Badan Pusat Statistik, Sumatera Barat.

Budiman dan Rijal. 2015. Analisis Potensi Sumberdaya Air Untuk Pengembangan dan IPCC. 2001.Climate Change 2001: Impacts, Adaptation, And Vulnerability.

Irawan, B. 2007. Fluktuasi Harga, Transmisi Harga, Marjin Pemasaran Sayur dan Buah. Pusat Analisis Sosial Ekonomi dan Kebijakan Pertanian, Bogor. 
Irsyad, F., Saptomo, Satyanto K.B., Setiawan, Indra. 2011. Analisis Perubahan Iklim Lokal dan Debit Di Das Cidanau. Pascasarjana Institut Pertanian Bogor. Jurnal Agromet. 25(1): 17-23.

Nazaruddin. 1999. Budidaya dan Pengaturan Panen Sayuran Dataran Rendah. Penebar Swadaya, Jakarta.

Nazir. 2005. Metode Penelitian. Ghalia Indonesia, Bogor.

Rahardi, F. 2000. Agribisnis Tanaman Sayur. Penebar Swadaya, Jakarta.

Sekretariat Jenderal Kementerian Pertanian.2015. Outlook Cabai. Pusat Data dan Sistem Informasi Pertanian. 79 hal.

Setyati H.S. 1989. Dasar-dasar Hortikultura. Jurusan Budidaya Pertanian. Institut Pertanian Bogor, Bogor.

Soekartawi. 2002. Prinsip Dasar Ekonomi Pertanian Teori dan Aplikasi. Raja Grafindo Persada, Jakarta.

Sudiyono, A. 2004. Pemasaran Pertanian. Universitas Muhammadiyah Malang, Malang

Suryani, A. 2008. Analisis Faktor-Faktor Yang Mempengaruhi Produksi Usahatani Kubis. Fakultas Pertanian Institut Pertanian Bogor, Bogor.

Syahza, A. 2007. Model Pemasaran Produk Pertanian Berbasis Agribisnis Sebagai Upaya Percepatan Pertumbuhan Ekonomi Pedesaan. Lembaga Penelitian Universitas Riau, Pekanbaru. 